\title{
1 Forest fire survival in young, dense Betula ermanii stands on soil scarification sites
}

3 Masato Hayamizu*, Yasutaka Nakata, Hiroyuki Torita

4 Forestry Research Institute, Hokkaido Research Organization, Higashiyama, Bibai, Hokkaido

5 079-0198, Japan

6

$7 *$ Corresponding author

8 Present address: Forestry Research Institute, Hokkaido Research Organization, Higashiyama,

9 Bibai, Hokkaido 079-0198, Japan

10 Tel: $+81-0126-63-4164$

11 E-mail address: hayamizu-masato@hro.or.jp 
13

\section{Abstract}

A forest fire in a cool-temperate broad-leaved forest in northern Japan, from 26 May to 19 June 2019, provided an opportunity to examine its effects on young and dense birch (Betula ermanii Cham.) stands in soil scarification sites. To characterise post-fire responses (survival and resprouting) of birch, we set up two plots, 6 months post fire. We investigated trunk diameter at breast height and burn marks on tree trunks (scorch height and charring percentage around the tree bole) of all B. ermanii trees in both plots. Survival and resprouting of each tree were monitored over 2 years ( 6 and 16 months post fire). To quantify post-fire vegetation recovery in the forest floor, we manually mapped the dominant understory plant, dwarf bamboo (i.e. Sasa kurilensis (Rupr.) Makino et Shibata), from orthomosaic images obtained by an unmanned aircraft vehicle, and estimated the recovery rate in the second year post fire. Additionally, seedlings of woody species were counted in both plots.

Size-dependent survival rates of plants in both plots were similar in the first year post fire. All B. ermanii trees died without resprouting in the second year post fire, indicating the lethal effects of fire on young birch trees. Moreover, a high recovery rate of dwarf bamboos over 2 years in both plots and limited seedling establishment of woody plants suggest that the fire resulted in regeneration failure of young stands in the scarification sites. On the basis of these findings, we propose future management of stands in soil scarification sites post fire, considering the vulnerability of young trees and the rapid change in vegetation from young forest to dense birch cover post fire. 


\section{Introduction}

Fire is a common natural disturbance in forests worldwide and affects the dynamics of vegetation in various forest ecosystems (Bowman et al., 2009). In fire-prone ecosystems, post-fire natural regeneration enables the persistence of forest vegetation, even after the destruction of large number of trees (Fernandes et al., 2008; Catry et al., 2013). However, the survival capacity of plants is not well understood in less fire-prone ecosystems, owing to limited opportunities to examine the process of post-fire vegetation dynamics (Goto et al., 1996). Moreover, during recent decades, forest fires have been increasing due to human activities and climate change (Flannigan et al., 2013; Keeley et al., 2019). Therefore, understanding post-fire vegetation dynamics in less fire-prone ecosystems is as important as it is in fire-prone ecosystems (Tepley et al., 2018).

Many plant species typically regenerate via two adaptive strategies post fire: seedling generation from seeds (Keeley and Fotheringham, 2000) and resprouting from roots and stumps (Bond and Midgley, 2001; Pausas and Keeley, 2014). Previous studies in fire-prone forests have demonstrated rapid recovery post fire through a flush of germination (Roy and Sonie, 1992; Tyler, 1995) and rapid vegetative resprouting (Catry et al., 2013;

Stevens-Rumann and Morgan, 2016). In cool-temperate broad-leaved forests in northern Japan, where plants are not adapted to fire (Nakagoshi et al., 1987), forest vegetation can still regenerate post fire (Masaka et al., 2000; Goto, 2004). In particular, post-fire seed production and resprouting involves large and mature trees (Masaka et al., 2000). Higher canopies and thicker barks make larger trees more resistant to the heat of fire than smaller trees, and thus, larger trees are more likely to survive (Gill and Ashton, 1968; Pausas, 2015). This resilience of larger trees to heat damage is manifested as their ability to allocate resources within seeds, enabling resprouting post fire (Masaka et al., 2004). On the contrary, young forests with small trees are considered more vulnerable to fire and less resilient than mature forests. However, 
there are only a few studies on the response of cool-temperate broad-leaved forests to fire disturbances, especially those focusing on post-fire survival and regeneration in young forest stands.

Another cause for the failure of natural regeneration is the inhibition of seedling establishment and growth through dense understory plants (Watt, 1919; Mallik, 2003).

Several plant species can rapidly recover post fire, cover the forest floor faster than that under forest establishment, and demonstrate sprouting of tree seedlings in fire-prone coniferous forests (Mallik, 2003). In cool-temperate broad-leaved forests, the ground cover is frequently dominated by a dense evergreen understory of dwarf bamboos, Sasa kurilensis (Rupr.) Makino et Shibata (Masaki et al., 1999, Matsuo et al. 2018). In northern Japan, dwarf bamboos reproduce vegetatively from their root systems to form a dense cover after less severe disturbances (Goto, 2004), which inhibit seedling emergence and survival of tree species (Taylor and Zisheng, 1992; Noguchi and Yoshida, 2004). Since the 1970s, soil scarification, by which both understory dwarf bamboos and surface soil are removed using engineering machinery, has been widely applied for assisted natural regeneration in natural forest management in northern Japan (Umeki, 2003; Ito et al., 2018). More than 45,000 hectares of soil scarification sites have been established in Hokkaido, northern Japan (Ito et al., 2018). Moreover, Umeki (2003) reported that 122 (84\%) of the 146 stands surveyed in scarification sites in Hokkaido were young forest stands (13-22 years). Therefore, most of the stands in soil scarification sites in Hokkaido are still expected to be young forests, less than 30 years old.

Betula ermanii Cham. is a major broad-leaved tree species in cool-temperate mixed forests in northern Japan (Kikuzawa, 1988). B. ermanii is considered a pioneer species with disturbance-related characteristics such as high dispersal ability and fast growth potential in disturbed sites (Kikuzawa, 1988). It is the most dominant species and forms monospecific, 
even-aged stands in soil scarification sites (Umeki, 2003). Moreover, this species has the ability to sprout from the base of the trunk and is known to play an important role in the persistence of individuals under severe environments (Okitsu, 1991). However, little is known about the responses of young birch trees post fire disturbance (especially on survival and germination) and the responses of forest floor vegetation that affects post-fire natural regeneration of birch trees.

In Hokkaido, large-scale fire disturbances occurred at a higher frequency before the start of the $20^{\text {th }}$ century (Takaoka and Sasa, 1996), but according to the Japan Ministry of Agriculture, Forestry and Fisheries, relatively small-scale fires continue to occur sporadically. Owing to the humid temperate regions in northern Japan, the intensity of fires is estimated to be within the range of surface fire line intensities, as reported in forests in the United States and Canada (Goto et al., 2005). Although most of the young forest stands in soil scarification sites in Hokkaido have not yet experienced fires, we hypothesised that the vulnerability of young trees to catch fire and the resilience of the dwarf bamboos result in regeneration failure of cool-temperate broad-leaved tree species.

A forest fire that started in Ōmu Town, north-western Hokkaido in May 2019 burned 214.79 ha of forest. This was the largest surface fire in Hokkaido in terms of area and scale in the past 30 years (Hokkaido Government, 2019). This provided an opportunity to examine the effects of fire on the survival of young birch forests and examine the recovery of understory vegetation dominated by dwarf bamboo. In this study, post-fire responses of $B$. ermanii trees in scarification sites were evaluated to examine the survival and resprouting of dense, young birch forests. The objectives of this study were to: (1) characterise the post-fire responses, especially survival and resprouting, of B. ermanii trees and (2) quantify vegetation recovery in the forest floor post fire. Here, we discuss the post-fire natural regeneration of $B$. ermanii stands in soil scarification sites. 


\section{Materials and Methods}

110

\section{Study sites}

The study sites are located in the scarification sites in Ōmu Town (Figure 1a and 1b). A fire was first detected on 26 May 2019 and was finally declared to be under control in this area on 19 June 2019. The vegetation on the forest floor in the study areas was almost completely destroyed by the fire (Figure 1c and 1d). The fire spread across 214.79 ha, comprising 165.83 ha of a secondary cool-temperate broad-leaved forest and 48.96 ha of a plantation coniferous forest. There are no records of previous fires in these study sites (Hokkaido Government, 2019). The weather during the fire was sunny, with a mean temperature of $25.5^{\circ} \mathrm{C}$ (maximum temperature; $32.4^{\circ} \mathrm{C}$ ), mean humidity of $39 \%$, maximum wind velocity of $13.8 \mathrm{~ms}^{-1}$, and maximum instantaneous wind speed of $24.2 \mathrm{~ms}^{-1}$, with a southeast wind direction (Japan Meteorological Agency, 2019). Ōmu Town belongs to the Okhotsk climatic zone, and the forest floor is usually snow-covered from December to April in the subsequent year. In May, the frequency of high-temperature events was higher in Okhotsk area relative to that in other areas (Mori and Sato, 2014). Combined with droughts caused by the foehn wind, the surface fire fanned by the foehn winds burned the study area soon after the disappearance of snow cover (Mori and Sato, 2014; Hokkaido Government, 2019). The elevation of the site ranges from 500 to $560 \mathrm{~m}$. Soil scarification was conducted in 1989, and the age of the B. ermanii forest stands was 30 years or less in 2019.

\section{Field survey and data collection}

In the forest fire sites, two plots of burned B. ermanii stands were established in scarification sites on 30 October 2019. In Plot 1, which was scarified in a rectangular shape in 1989, a 10 $\mathrm{m} \times 50 \mathrm{~m}$ quadrat was set up on a gentle southeast-facing slope at an altitude of $560 \mathrm{~m}$. In 
132 Plot 2, which was scarified in a square shape in 1989, a $20 \mathrm{~m} \times 20 \mathrm{~m}$ quadrat was set up on a gentle south-facing slope at an altitude of $503 \mathrm{~m}$ (Figure 2).

To examine tree mortality and resprouting after a fire, only trees with a diameter at breast height $(\mathrm{DBH})$ of above $0.7 \mathrm{~cm}$ were sampled; overall $112 \mathrm{~B}$. ermanii trees were measured and observed in Plot 1 and 115 birch trees were measured and observed in Plot 2. Data were collected from 30 October to 1 November 2019 (6 months post-fire) and on 10 September 2020 (16 months post-fire). Trees in the study plot were tagged, their DBH was measured to the nearest $1 \mathrm{~cm}$ at $1.3 \mathrm{~m}$ above the ground level, and new sprouts were counted. Tree size measurements included the DBH for all birch trees (Plot 1, $N=112$; Plot 2, $N=114$; Table 1). Tree height and clear length of randomly selected representative trees in the plot were measured (Plot 1, $N=6$; Plot 2, $N=10$; Table 1). Tree survival was divided into binary categories by visual inspection of crown condition: 0 , dead, no foliage or sprouts in the crown; 1, alive, foliage survived, and sprouts or inflorescence buds were present in the crown. Scorch height and bole charring percentage (stem damage), which is correlated with fire intensity, of all individuals were measure. The values for the plot and transect variables (Table 1) were used to characterise all trees in a given plot.

To estimate the extent to which the heat of the fire reached the belowground parts of the plant, burned litter depth was recorded in $1 \mathrm{~m} \times 1 \mathrm{~m}$ quadrats, randomly repeated three times in each plot, and was measured as the depth to which the burn marks reached in the litter layer, after measuring the depth of the litter layer (litter depth) of the plot. All canopy tree was recorded in each plot, 16 months post fire. Understory plants, especially seedling and other herbaceous months post fire. 
To estimate the recovery of dwarf bamboos, an unmanned aircraft vehicle (UAV; real time kinematic-UAV (RTK-UAV) Phantom 4 RTK (DJI Co., Shenzhen, China)) was used. The device was equipped with a D-RTK 2 high precision global navigation satellite system (GNSS) mobile station, which allowed real-time differentiation between the aircraft and the local GNSS system, or an RTK base station. The flight height was set to $100 \mathrm{~m}$ to acquire high-resolution orthorectified images. These images were created using the structure-from-motion and multi-view stereo algorithms. The algorithms automatically detect feature points to match with two-dimensional digital images. Based on the detected feature points of the target, three-dimensional spatial information of the target was acquired, and then an orthorectified image was created with this information. Metashape version 1.5.3 (Agisoft LLC, Saint Petersburg, Russia) was used to process the photographs. Ground truth and vegetation properties were recorded for all plant species by name. Culm height of the dwarf bamboos was directly calculated in plots 1 and 2, 16 months post fire.

\section{Data analysis}

The data were analysed using generalised linear models (GLMs). All statistical analyses were carried out using the statistical software R, version 3.6.2 (R Development Core Team, 2019). As dependent variables, we used post-fire tree responses, especially individual mortality, that is, mortality of all aboveground and belowground organs (tree death); these post-fire responses were examined in relation to different explanatory variables collected at the individual level (Table 1). For each response variable assessed, we started with a model including all the explanatory variables. Selection for the GLMs was performed with the R package 'MuMIn' to select the minimum Akaike information criterion (AIC) value, with

178 differences in $\mathrm{AICc}(\triangle \mathrm{AICc})>2$ used as evidence of substantial model dissimilarity (Barton, 179 2013). 
bioRxiv preprint doi: https://doi.org/10.1101/2020.09.20.305557; this version posted November $25,2020$. The copyright holder for this preprint (which was not certified by peer review) is the author/funder, who has granted bioRxiv a license to display the preprint in perpetuity. It is made available under aCC-BY-NC-ND 4.0 International license.

In both plots, the cover and recovery rates of the dwarf bamboos were calculated by manual mapping using RTK-UAV orthomosaic images at two time points, 6 and 16 months post fire. The UAV orthoimages were mapped and distinguished manually by a human interpreter in the GIS using ArcGIS software version 10.6 (ESRI Inc., Redlands, CA, USA).

\section{Results}

\section{Tree survival and resprouting}

The 227 surveyed trees showed a clear size-dependent high mortality rate (Table 2, Figures 3 and 4). Post-fire mortality was 75.9\% in Plot 1 and $72.2 \%$ in Plot 2 at 6 months post fire. Despite careful observation, post-fire mortality was $100 \%$ in both plots at 16 months post fire. In Plot 1, with a modal DBH of $3 \mathrm{~cm}$ and stand density of 2240 trees ha- ${ }^{-1}$, all plants with a DBH less than $5 \mathrm{~cm}$ died. The mean DBH of dead individuals was $5.32 \pm 0.35 \mathrm{~cm}$ (mean \pm standard error (SE)). The DBH of surviving individuals showed a modal value of $10-12 \mathrm{~cm}$ with a mean $\mathrm{DBH}$ of $10.57 \pm 0.69($ mean $\pm \mathrm{SE})$. The survival rate was $24.1 \%$, and the mean $\mathrm{DBH}$ of the surviving trees was significantly higher than that of the dead trees $(t$-test, $P<$ 0.01; Table 2). The survival rate of trees in Plot 2, with a stand density of 2875 trees ha ${ }^{-1}$, showed the same tendency as in Plot 1 . The modal DBH was $3 \mathrm{~cm}$, and all individuals with a DBH of less than $5 \mathrm{~cm}$ died. As in Plot 1, resprouting from the burnt bases of B. ermanii stems was not observed in Plot 2. The mean DBH of the dead individuals was $4.18 \pm 0.20 \mathrm{~cm}$. The DBH of the surviving individuals was mostly $7-8 \mathrm{~cm}$, with a mean DBH of $8.97 \pm 0.42$ $\mathrm{cm}$. The survival rate was $27.8 \%$, and the mean DBH of the surviving individuals was significantly higher than that of the dead trees ( $t$-test, $P<0.01$; Table 2$)$.

In the GLM analysis, DBH showed significant effect on probability of survival of B. ermanii, whereas scorch height and stem damage were not significantly different from one another (Table 3). The probability of survival of B. ermanii showed significant dependence on DBH 
in both plots (Figure 4), which was consistently included in the best models (Supplemental Table 1).

Despite careful observation, resprouting from the burnt bases of the B. ermanii stems was not observed in Plots 1 and 2 at 16 months post fire.

\section{Post-fire recovery of dwarf bamboos}

The UAV-captured images revealed a rapid recovery of dwarf bamboos within 16 months post fire (Figures 5 and 6). Immediately after the fire, the aboveground portion was completely destroyed (Figure 1d). Six months post fire, the dwarf bamboos recovered to levels of $24.33 \%$ and $25.52 \%$ in Plots 1 and 2, respectively. Sixteen months post fire, the dwarf bamboo cover was $87.04 \%$ and $84.97 \%$ in Plots 1 and 2, respectively. The recovery rate at 10 months post fire was $62.71 \%$ and $59.45 \%$ in Plots 1 and 2, respectively (Figure 6). Field survey at 16 months post fire showed that the culm height was $67.8 \pm 8.5$ and $94.2 \pm 7.0$

$216 \mathrm{~cm}$ in Plots 1 and 2, respectively.

\section{Post-fire vegetation and seedling emergence}

218 Very few seedlings were established 16 months post fire in both plots (Table 4). The canopy

219 tree species were Abies sachalinensis (Schmidt), Alnus japonica, Quercus crispula Blume,

220 Phellodendron amurense Rupr., Cornus controversa Hemsl., and Salix bakko Kimura. In Plot

221 1, one individual each of $P$. amurense, Acer pictum Thumb. mono (Maxim.), and Actinidia

222 arguta was recorded. In Plot 2, one individual each of Aralia elata and A. arguta was

223 recorded. Seedlings of $B$. ermanii were not established in both plots.

\section{Discussion}


This study demonstrated the lethal effects of a fire on young $B$. ermanii trees within 2 years. The survival probability was clearly size-dependent in both plots, with larger trees (DBH > $8.9 \mathrm{~cm}$ ) showing more tolerance to the fire in the first year (Table 2, Figures 3 and 4).

Additionally, the relationship between fire tolerance and tree size has been recognised in fire-prone ecosystems such as the Siberian taiga (Uemura et al., 1990) and Australian eucalyptus-dominated forests (Gill and Ashton, 1968). A previous study on B. ermanii trees in cool-temperate broad-leaved forests reported that many trees tended to die within a few years even if their canopies survived immediately after a forest fire (Sasa et al., 1992). The results of these previous studies and the present study support the hypothesis that young forests are vulnerable to fire.

Post-disturbance resprouting is considered a common feature of Betula species (Perala and Alm, 1990; de Groot and Wein, 2004). In addition, based on a survey of old B. ermanii trees (probably >100 years) in the forest limit of high mountains in Central Japan, Okitsu (1991) reported that the percentage of resprouting (multiple-stemmed tree) B. ermanii trees was $25 \%-50 \%$. This suggested that B. ermanii trees have the potential to resprout and play an important role in individual persistence. In contrast, in the present study, post-fire resprouting was not evident in young B. ermanii trees ( $<30$ years) in both years. In particular, sprouting was not observed even from surviving individuals $(\mathrm{DBH}>8 \mathrm{~cm})$ at 6 months post fire, indicating that there was no response to fire regardless of survival. Thus, the low survival rate and lack of resprouting among the young trees demonstrate their vulnerability to fire damage and inability to allocate resources towards resprouting. Moreover, this phenomenon indicates that young $B$. ermanii trees are difficult to regenerate via resprouting post fire.

\section{Rapid recovery of dwarf bamboo and regeneration failure of young birch trees}

We quantified dwarf bamboo coverage in both plots at 6 and 16 months post fire and found that the forest floor was densely and exclusively re-covered within 16 months post fire 
(Figures 5 and 6). Dwarf bamboos can dominate the forest floor through asexual reproduction after less severe disturbances (Sasa et al., 1992; Matsuo et al. 2018). In the present study plots, the litter was only partially charred on the surface (Table 1). These results suggest that the fire caused relatively negligible damage to the belowground parts of the dwarf bamboos and showed strong resilience via vegetative reproduction in a short term than previously thought.

In addition to forest floor cover and recovery rates, the culm height of dwarf bamboos in both plots recovered by more than $50 \mathrm{~cm}$ (maximum height: $138 \mathrm{~cm}$; Supplemental Figure 1) despite their complete destruction by the fire (Figure 1d). Sasa kurilensis cover is especially thick, where the culms reach a height of over 2 m (Oshima, 1962; Noguchi and Yoshida, 2005). In such areas, thick and dense dwarf bamboo covers block the light to seedlings and inhibit tree regeneration by preventing seedling establishment and suppressing seedling growth (Kobayashi et al., 2004). Moreover, canopy removal by a fire is a critical mechanism that changes the structure and composition of forest vegetation (Mallik, 2003; Bond and Keeley, 2005; Dantas et al., 2016). For example, in boreal and fire-prone temperate conifer forests, fire disturbances have been reported to cause regeneration failure for a long term due to rapid vegetative growth of understory ericaceous plants such as Kalmia angustifolia L (Mallik, 2003) and Vaccinium myrtillus L. (Mallik and Pellissier, 2000). These shrubs show a positive response to canopy gaps under higher light environments. Similarly, our UAV survey of dwarf bamboos suggests that the species can not only recover the aboveground parts immediately after the fire via the underground culm but also rapidly recover the aboveground biomass lost due to forest canopy removal (Figures 5 and 6).

Our findings of a high rate of mortality and lack of resprouting elucidated the vulnerability of young birch stands to fire. This indicates that young B. ermanii trees are unlikely to resprout for post-fire regeneration. Moreover, B. ermanii seedlings were not evident 16 months post fire under dense dwarf bamboo cover (Table 4). These results suggest that B. ermanii trees 
fail to successfully regenerate via seeds and resprouting under dense dwarf bamboo cover. In the dense dwarf bamboo understory, the emergence of tree species was almost inhibited regardless of the dispersal of new seeds (Nakashizuka, 1988; Doležal et al., 2009). In addition, increased dwarf bamboo biomass reduces tree seedling density and plant species diversity in various forest understories (Nakashizuka, 1988; Hiura et al., 1996; Narukawa and Yamamoto, 2002; Noguchi and Yoshida, 2004). Therefore, here, the dense and thick cover of dwarf bamboos that recovered post fire continued to inhibit the establishment of tree seedlings, resulting in regeneration failure.

\section{Implications for management}

The vulnerability of young trees to fire demonstrates the importance of appropriate post-fire management in scarification sites even in cool-temperate broad-leaved forests. Dwarf bamboos in the study plots were largely removed by soil scarification in 1989. This species later invaded the soil scarification sites and recovered the forest floor with a resilience sufficient to tolerate the current level of fire disturbance for the next 30 years. Here, according to the UAV orthoimages and field survey (Supplemental Figure 1), many large and mature (mother) trees of B. ermanii (height $>10 \mathrm{~m}$ and DBH $>40 \mathrm{~cm}$; Masato Hayamizu's personal observation) were observed around Plots 1 and 2. It is known that birch seeds are typically dispersed over relatively long distances; however, the closer the tree is to a mature tree, the greater the supply of birch seeds (Perala and Alm, 1990). Therefore, removing dwarf bamboos as soon as possible after a fire (e.g. early post-fire soil scarification) is an option for forest management through reforestation.

Soil scarification is a commonly used 'close to nature' forest management method that assists the natural regeneration of woody plants in various forest biomes, with widespread research globally, including Europe (Hynynen et al., 2010; Nilsson et al., 2010; Jäärats et al., 2012), the United States (Woolley et al., 2012), and Canada (Beaudry et al., 1997; Giasson et al., 
bioRxiv preprint doi: https://doi.org/10.1101/2020.09.20.305557; this version posted November 25,2020 . The copyright holder for this preprint (which was not certified by peer review) is the author/funder, who has granted bioRxiv a license to display the preprint in perpetuity. It is made available under aCC-BY-NC-ND 4.0 International license.

2006), with recent reports from South-Central Chile (Soto and Puettmann, 2018), Lebanon (Nakhoul et al., 2020), and Japan (Umeki, 2003). Globally, the concept of 'close to nature' has garnered attention, and it aims to reconcile wood production and ecological resilience (Messier et al., 2013; O’Hara, 2016). Furthermore, soil scarification is of importance in this context. During recent years, several studies have focused on the spatial distribution (Ito et al., 2019 a) and association among soil physicochemical properties (Ito et al., 2019 b) of $B$. ermanii stands in soil scarification sites, because of an increasing commercial demand for Japanese birch trees (Ito et al., 2018). However, information on the response and risk management to disturbances, including fire, in young forests post soil scarification is limited. The vulnerability of young forests and the factors involved in regeneration failure identified in this study suggest that future studies should focus on post-disturbance responses and risk assessment of young, dense stands in soil scarification sites.

\section{Conclusion}

This study demonstrated the negative effects of a forest fire on young B. ermanii trees and elucidated the factors that contribute to the post-fire natural regeneration failure of young and dense stands in scarification sites. Young tree survival strongly depends on the tree diameter (DBH), and all birch trees died within 16 months of the fire. Moreover, (i) no resprouting was observed in any individual of B. ermanii trees, (ii) the rapid recovery of the dwarf bamboos covered nearly $90 \%$ of the forest floor within 16 months post fire, and (iii) a few seedlings of woody plant species emerged in forest understory covered by dense dwarf bamboos, suggesting that natural regeneration failure will continue in post-fire soil scarification sites. In particular, differences in fire tolerance and resilience between B. ermanii trees and dwarf bamboos are a major factor resulting in rapid vegetation change in cool-temperate broad-leaved forests in northern Japan. An evaluation of post-disturbance responses of young stands is necessary to understand whether this trend varies across regions and species. 


\section{Funding}

327 This work was supported by a research fund of the Hokkaido Research Organization.

\section{Acknowledgements}

330 We thank the Hokkaido Government Okhotsk General Subprefectural Bureau Western

331 Forestry Management for providing the data. We thank Ogura Takuro for assistance in the

332 GIS analysis and Ebina Masuto for assistance and sharing valuable information. We thank

333 Editage for English language editing.

\section{Conflicts of Interests}

336 The authors declare that they have no known competing financial interests or personal

337 relationships that could influence the work reported in this paper.

\section{Data Availability Statement}

340 Data of this study will be available from the corresponding author upon request. 


\section{References}

Bartoń, K. 2013 MuMIn: Multi-Model Inference, R package version 1.9. 13.

Beaudry, S., Duchesne, L.C. and CôTé, B. 1997 Short-term effects of three forestry practices on carabid assemblages in a jack pine forest. Can. J. For. Res. 27, 10. doi:10.1139/x97-171.

Bond, W. and Keeley, J. 2005 Fire as a global 'herbivore': the ecology and evolution of

Bond, W.J. and Midgley, J.J. 2001 Ecology of sprouting in woody plants: the persistence niche. Trends Ecol. Evol. 16, 45-51. doi:0.1016/S0169-5347(00)02033-4.

Catry, F.X., Moreira, F., Tujeira, R. and Silva, J.S. 2013 Post-fire survival and regeneration of

Dantas, V. de L., Hirota, M., Oliveira, R.S. and Pausas, J.G. 2016 Disturbance maintains alternative biome states. Ecol. Lett. 19, 12-19. doi: 10.1111/ele.12537. glandulosa growth dynamics. Int. J. Wildland Fire. 13, 287. doi: 10.1071/WF03048. 
Flannigan, M., Cantin, A.S., de Groot, W.J., Wotton, M., Newbery, A. and Gowman, L.M.

2013. Global wildland fire season severity in the 21st century. For. Ecol. Manag. 294, 54-61. doi: 10.1016/j.foreco.2012.10.022.

Giasson, M.-A., Coursolle, C. and Margolis, H.A. 2006 Ecosystem-level CO2 fluxes from a boreal cutover in eastern Canada before and after scarification. Agric. For. Meteorol. 140, 23-40. doi: 10.1016/j.agrformet.2006.08.001.

Gill, A.M. and Ashton, D.H. 1968 The role of bark type in relative tolerance to fire of three central Victorian Eucalypts. Aust. J. Bot. 16, 491-498. doi: 10.1071/BT9680491.

Goto, Y. 2004 Early post-fire vegetation regeneration in Larix kaempferi artificial forests with an undergrowth of Sasa senanensis: early post-fire vegetation regeneration. Ecol. Res. 19, 311-321.doi: 10.1111/j.1440-1703.2004.00640.x.

Goto, Y., Tamai, K., Miyama, T. and Kominami, Y. 2005 Forest fire intensity in Japan:

Estimation of Byram's fireline intensity using Rothermel's fire spread model. J. Jpn. For. Soc.

87, 193-201. doi: 10.1007/s10310-005-0169-4. doi: 10.1007/BF00044698.

Goto, Y., Yoshitake, T., Okano, M. and Shimada, K. 1996 Seedling regeneration and vegetative resprouting after fires in Pinus densiflora forests. Vegetatio. 122, 157-165.doi: 10.1007/BF00044698.

Hiura, T., Sano, J. and Konno, Y. 1996 Age structure and response to fine-scale disturbances of Abies sachalinensis, Picea jezoensis, Picea glehnii, and Betula ermanii growing under the

383 influence of a dwarf bamboo understory in northern Japan. Can. J. For. Res. 26, 289-297. doi: $10.1139 / \times 26-032$.

Hokkaido Government 2019 Summary report of the forest fire occurred in May 2019 in Ōmu 
Forest (Abashiri West Management Area), Japan. (in Japanese). Available online:

http://www.town.oumu.hokkaido.jp/hotnews/detail/00004860.html (accessed on 25

November 2020)

Hynynen, J., Niemisto, P., Vihera-Aarnio, A., Brunner, A., Hein, S. and Velling, P. 2010

Silviculture of birch (Betula pendula Roth and Betula pubescens Ehrh.) in northern Europe.

Forestry. 83, 103-119. doi: 10.1093/forestry/cpp035.

393

394
Ito E., Hashimoto T., Aizawa S., Furuya N. and Ishibashi S. 2019 Association of soil physicochemical properties following scarification with regenerated birch growth in Hokkaido, northern Japan. Bull. FFPRI. 18, 345-353. doi: 10.20756/ffpri.18.4_345.

Ito, E., Hashimoto, T., Aizawa, S., Furuya, N. and Ishibashi, S. 2019 Spatial distribution of regenerated birch trees in strip-scarified stands. Bull. FFPRI. 18, 213-218. doi:

10.20756/ffpri.18.2_213.

Ito, E., Hashimoto, T., Aizawa, S. and Ishibashi, S. 2018 Contemporary significance of soil scarification for promoting tree regeneration in Hokkaido, northern Japan. Jpn. J. For.

Environ. 60, 71-82. doi: 10.18922/jjfe.60.2_71.

Jäärats, A., Sims, A. and Seemen, H. 2012 The effect of soil scarification on natural regeneration in forest microsites in Estonia. Balt. For. 18 (1), 133-143 Available online: https://www.balticforestry.mi.lt/bf/PDF_Articles/2012-18[1]/Jaarats_2012\%2018\%20(1) _133_143.pdf (accessed on 25 November 2020).

Japan Meteorological Agency. 2019. Past weather data and download. Available at: https://www.data.jma.go.jp/obd/stats/etrn/(accessed on 25 November 2020). 
bioRxiv preprint doi: https://doi.org/10.1101/2020.09.20.305557; this version posted November 25,2020 . The copyright holder for this preprint (which was not certified by peer review) is the author/funder, who has granted bioRxiv a license to display the preprint in perpetuity. It is made available under aCC-BY-NC-ND 4.0 International license.

Keeley, J. and Fotheringham, C. 2000 Role of Fire in Regeneration from Seed. In Seeds: The Ecology of Regeneration in Plant Communities. M. Fenner (2nd edn). CABI, pp. 311-330. doi: 10.1079/9780851994321.0311.

Keeley, J.E., van Mantgem, P. and Falk, D.A. 2019 Fire, climate and changing forests. Nat. Plants. 5, 774-775. doi: 10.1038/s41477-019-0485-x.

Kikuzawa, K. 1988 Intraspecific competition in a natural stand of Betula ermanii. Ann. Bot. 61, 727-734. doi: 10.1093/oxfordjournals.aob.a087611.

Kobayashi, T., Shimano, K. and Muraoka, H. 2004 Effect of light availability on the carbon gain of beech (Fagus crenata) seedlings with reference to the density of dwarf bamboo (Sasa kurilensis) in an understory of Japan Sea type beech forest. Plant Species Biol. 19, 33-46. doi: 10.1111/j.1442-1984.2004.00099.x.

Mallik, A.U. 2003 Conifer regeneration problems in boreal and temperate forests with ericaceous understory: role of disturbance, seedbed limitation, and keytsone species change. Crit. Rev. Plant Sci. 22, 341-366. doi: 10.1080/713610860.

Masaka, K., Ohno, Y. and Yamada, K. 2000 Fire tolerance and the fire-related sprouting characteristics of two cool-temperate broad-leaved tree species. Ann. Bot. 85, 137-142. doi: 10.1007/s 10310-004-0090-2.

Masaka, K., Ohno, Y. and Yamada, K. 2004 Recovery of canopy trees and root collar sprout growth in response to changes in the condition of the parent tree after a fire in a cool-temperate forest. J. For. Res. 9, 271-275. doi: 10.1006/anbo.1999.1007.

Masaki, T., Tanaka, H., Tanouchi, H., Sakai, T. and Nakashizuka, T. 1999 Structure, dynamics and disturbance regime of temperate broad-leaved forests in Japan. J. Veg. Sci. 10, 805-814. doi: $10.2307 / 3237305$. 
bioRxiv preprint doi: https://doi.org/10.1101/2020.09.20.305557; this version posted November 25, 2020. The copyright holder for this preprint (which was not certified by peer review) is the author/funder, who has granted bioRxiv a license to display the preprint in perpetuity. It is made available under aCC-BY-NC-ND 4.0 International license.

Matsuo, A., Tomimatsu, H., Sangetsu, Y., Suyama, Y. and Makita, A. 2018. Genet dynamics of a regenerating dwarf bamboo population across heterogeneous light environments in a temperate forest understorey. Ecol. Evol. 8, 1746-1757. doi: 10.1002/ece3.3793.

\section{Messier, C.C., Puettmann, K.J. and Coates, K.D. 2014 Managing Forests as Complex}

Adaptive Systems: Building Resilience to the Challenge of Global Change. 1st edn. Routledge, $368 p p$.

Mori, K. and Sato, T. 2014 Spatio-temporal variation of high-temperature events in Hokkaido, North Japan. J. Meteorol. Soc. Jpn. Ser II. 92, 327-346. doi: 10.2151/jmsj.2014-404.

Nakagoshi, N., Nehira, K. and Takahashi, F. 1987 The role of fire in pine forests of Japan. Role Fire Ecol. Syst. 91-119. Available online:

https://www.researchgate.net/profile/Nobukazu_Nakagoshi/publication/313208672_The_role _of_fire_in_pine_forests_of_Japan/links/58f95bbf0f7e9ba3ba4c66f9/The-role-of-fire-in-pineforests-of-Japan.pdf (accessed on 25 November 2020).

Nakashizuka, T. 1988 Regeneration of beech (Fagus crenata) after the simultaneous death of undergrowing dwarf bamboo (Sasa kurilensis). Ecol. Res. 3, 21-35. doi: 10.1007/BF02348692.

Nakhoul, J. Santonja, M. Fernandez, C. Greff, S. Bousquet-Mélou, A. Dupouyet, S. Nemer, N., Kattar, S., Abboud, J., Prévosto, B., 2020 Soil scarification favors natural regeneration of Pinus pinea in Lebanon forests: Evidences from field and laboratory experiments. For. Ecol. Manag. 459 , 117840. doi:10.1016/j.foreco.2019.117840.

Narukawa, Y. and Yamamoto, S. 2002 Effects of dwarf bamboo (Sasa sp.) and forest floor microsites on conifer seedling recruitment in a subalpine forest, Japan. For. Ecol. Manag. 163, 61-70. doi: 10.1016/S0378-1127(01)00527-8. 
Nilsson, U., Luoranen, J., Kolström, T., Örlander, G. and Puttonen, P. 2010 Reforestation with planting in northern Europe. Scand. J. For. Res. 25, 283-294. doi:

Noguchi, M. and Yoshida, T. 2005 Factors influencing the distribution of two co-occurring dwarf bamboo species (Sasa kurilensis and S. senanensis) in a conifer-broadleaved mixed stand in northern Hokkaido. Ecol. Res. 20, 25-30. doi: 10.1007/s11284-004-0009-6.

Noguchi, M. and Yoshida, T. 2004 Tree regeneration in partially cut conifer-hardwood mixed

Manag. 190, 335-344. doi: 10.1016/j.foreco.2003.10.024. 1-6. doi: 10.1093/forestry/cpv043.

Okitsu, S. 1991 Multiple-stem formation of Betula ermanii growing at the forest limit on the high mountains of central Japan. Tech. Bull. Fac. Hortic. Chiba Univ. 141-146. Available online: https://agriknowledge.affrc.go.jp/RN/2030461557.pdf (accessed on 25 November 2020).

Oshima, Y. 1962 Ecological studies of Sasa communities. V. Influence of light intensity, snow depth and temperature upon the development of Sasa kurilensis community. Bot Mag Tokyo. 75, 43-48. Available online:

472 https://www.jstage.jst.go.jp/article/jplantres1887/75/884/75_884_43/_pdf (accessed on 25 473 November 2020).

474 Pausas, J.G. 2015 Bark thickness and fire regime. Funct. Ecol. 29, 315-327. doi: 
Pausas, J.G. and Keeley, J.E. 2014 Evolutionary ecology of resprouting and seeding in fire-prone ecosystems. New Phytol. 204, 55-65. doi: 10.1111/nph.12921.

Perala, D.A. and Alm, A.A. 1990 Reproductive ecology of birch: a review. For. Ecol. Manag. 32, 1-38. doi: 10.1016/0378-1127(90)90104-J.

R Development Core Team. 2019 R (version 3.6.2). R: A language and environment for statistical computing. Vienna, Austria. Available at: http://www. R-project. org.

Roy, J. and Sonie, L. 1992 Germination and population dynamics of Cistus species in relation to fire. J. Appl. Ecol. 29, 647. doi: 10.2307/2404472.

Sasa, K., Satoh, F., Fujiwara, K., Yamada, K. and Takaoka, S. 1992 Three-year changes of Sasa senanensis community after destruction by fire. Trans. Meet. Hokkaido Branch Jpn. For. Soc. 40, 50-52. (in Japanese). Available online:

https://www.jstage.jst.go.jp/article/jfshb/40/0/40_KJ00009035873/_pdf/-char/ja (accessed on 25 November 2020)

Soto, D.P. and Puettmann, K.J. 2018 Topsoil removal through scarification improves natural regeneration in high-graded Nothofagus old-growth forests. J. Appl. Ecol. 55, 967-976. doi: 10.1111/1365-2664.12989.

Stevens-Rumann, C. and Morgan, P. 2016 Repeated wildfires alter forest recovery of mixed-conifer ecosystems. Ecol. Appl. 26, 1842-1853. doi: 10.1890/15-1521.1.

Takaoka, S. and Sasa, K. 1996 Landform effects on fire behavior and post-fire regeneration in the mixed forests of northern Japan. Ecol. Res. 11, 339-349. doi: 10.1007/BF02347791.

Taylor, A.H. and Zisheng, Q. 1992 Tree regeneration after bamboo die-back in Chinese Abies-Betula forests. J. Veg. Sci. 3, 253-260. doi: 10.2307/3235687. 
bioRxiv preprint doi: https://doi.org/10.1101/2020.09.20.305557; this version posted November $25,2020$. The copyright holder for this preprint (which was not certified by peer review) is the author/funder, who has granted bioRxiv a license to display the preprint in perpetuity. It is made available under aCC-BY-NC-ND 4.0 International license.

Tepley, A.J., Thomann, E., Veblen, T.T., Perry, G.L.W., Holz, A., Paritsis, J., et al. 2018 Influences of fire-vegetation feedbacks and post-fire recovery rates on forest landscape vulnerability to altered fire regimes. J. Ecol. 106, 1925-1940. doi: 10.1111/1365-2745.12950.

Tyler, C.M. 1995 Factors contributing to postfire seedling establishment in chaparral: direct and indirect effects of fire. J. Ecol. 83, 1009. doi: 10.2307/2261182.

Uemura, S., Tsuda, S. and Hasegawa, S. 1990 Effects of fire on the vegetation of Siberian taiga predominated by Larix dahurica. Can. J. For. Res. 20, 547-553. doi: 10.1139/x90-071.

Umeki, K. 2003 The regeneration of natural forests on Hokkaido, northern Japan. J. Jpn. For. Soc. 85, 246-251. doi: 10.11519/jjfs1953.85.3_246.

Watt, A.S. 1919 on the causes of failure of natural regeneration in British oakwoods. J. Ecol. 7, 173. doi: 10.2307/2255275.

Woolley, T., Shaw, D.C., Ganio, L.M. and Fitzgerald, S. 2012 A review of logistic regression models used to predict post-fire tree mortality of western North American conifers. Int. J. Wildland Fire. 21, 1. doi: 10.1071/WF09039. 
1 Table 1 Summary of the structural properties and assessed variables of Betula ermanii stands in scarification sites

\begin{tabular}{|c|c|c|c|c|c|c|c|c|c|}
\hline & $\begin{array}{l}\text { Area } \\
\text { (m) }\end{array}$ & $\begin{array}{l}\text { density } \\
\left(\mathrm{ha}^{-1}\right)\end{array}$ & $\begin{array}{l}\mathrm{DBH} \\
(\mathrm{cm} \pm \mathrm{SE})\end{array}$ & $\begin{array}{l}\text { Tree height } \\
(\mathrm{m} \pm \mathrm{SE})\end{array}$ & $\begin{array}{l}\text { Clear length } \\
(\mathrm{m} \pm \mathrm{SE})\end{array}$ & $\begin{array}{l}\text { Litter depth } \\
\qquad(\mathrm{cm} \pm \mathrm{SE})\end{array}$ & $\begin{array}{l}\text { Scorch height } \\
(\mathrm{m} \pm \mathrm{SE})\end{array}$ & $\begin{array}{l}\text { Stem damage } \\
\qquad(\% \pm \mathrm{SE})\end{array}$ & $\begin{array}{l}\text { Burned } \\
\text { litter depth } \\
(\mathrm{cm} \pm \mathrm{SE})\end{array}$ \\
\hline Plot 1 & $10 \times 50$ & 2240 & $5.32 \pm 0.35$ & $7.77 \pm 0.73$ & $3.64 \pm 0.33$ & $2.79 \pm 0.77$ & $1.49 \pm 0.10$ & $62.79 \pm 2.88$ & $1.39 \pm 0.38$ \\
\hline Plot 2 & $20 \times 20$ & 2875 & $5.51 \pm 0.28$ & $7.71 \pm 0.71$ & $4.08 \pm 0.32$ & $4.27 \pm 1.16$ & $0.68 \pm 0.03$ & $87.02 \pm 1.45$ & $0.96 \pm 0.19$ \\
\hline
\end{tabular}

DBH: Diameter at breast height, SE: Standard error 
3 Table 2 Summary of individual Betula ermanii survival at 6 months post fire.

\begin{tabular}{|c|c|c|c|c|}
\hline & & $N$ & $\mathrm{DBH}$ mean $\pm \mathrm{SE}(\mathrm{cm})$ & Survival rate $(\%)$ \\
\hline \multirow[t]{2}{*}{ Plot 1} & Alive & 27 & $10.57 \pm 0.69^{\mathrm{a}}$ & \multirow[t]{2}{*}{24.1} \\
\hline & Dead & 85 & $3.65 \pm 0.17^{\mathrm{b}}$ & \\
\hline \multirow[t]{2}{*}{ Plot 2} & Alive & 32 & $8.97 \pm 0.42^{\mathrm{a}}$ & \multirow[t]{2}{*}{27.8} \\
\hline & Dead & 83 & $4.18 \pm 0.20^{\mathrm{b}}$ & \\
\hline \multicolumn{5}{|c|}{ Means within a column followed by different superscript letters ( $\mathrm{a}$ and $\mathrm{b}$ ) are significantly } \\
\hline
\end{tabular}


8 Table 3 Generalized linear model (GLM) analyses of the effect of probability of survival of Betula ermanii.

\begin{tabular}{lcccc}
\hline & Estimate & SE & z value & $P$ value \\
\hline Intercept & -9.142 & 1.731 & -5.283 & $<0.001^{*}$ \\
DBH & 1.158 & 0.173 & 6.678 & $<0.001^{*}$ \\
Scorch height & 0.001 & 0.003 & 0.291 & 0.771 \\
Stem damage & 0.008 & 0.012 & 0.666 & 0.505
\end{tabular}

9 Asterisks (*) represent a statistical significance. DBH: diameter at breast height, SE: standard error 
Table 4 Summary of vegetation survey 16 months post fire.

\begin{tabular}{|c|c|c|c|}
\hline & Stratum & Species & $N$ \\
\hline \multirow[t]{11}{*}{ Plot 1} & Canopy & Phellodendron amurense Rupr & 3 \\
\hline & & Alnus japonica & 2 \\
\hline & & Cornus controversa Hemsl. & 1 \\
\hline & & Salix bakko Kimura. & 1 \\
\hline & Subcanopy & Sambucus racemosa ssp. kamtschatica & 1 \\
\hline & Shrub & Sasa kurilensis & $>100$ \\
\hline & & Eupatorium chinensis subsp. sachalinens & 12 \\
\hline & & Senecio cannabifolius & 3 \\
\hline & Seedling & Phellodendron amurense & 1 \\
\hline & & Acer pictum Thumb. Mono & 1 \\
\hline & & Actinidia arguta & 1 \\
\hline \multirow[t]{6}{*}{ Plot 2} & Canopy & Abies sachalinensis (Schmidt) & 2 \\
\hline & & Quercus crispula Blume & 2 \\
\hline & Subcanopy & - & - \\
\hline & Shrub & Sasa kurilensis & $>100$ \\
\hline & Seedling & Actinidia arguta & 1 \\
\hline & & Aralia elata & 1 \\
\hline
\end{tabular}

$11 N$ : absolute shoot number 


\section{Figure legends}

3 Figure 1. Map and location of Ōmu Town, Hokkaido, Japan. Location of the two study sites

4 (a). Black dots represent the study plots, and the area surrounded by the black line indicates

5 the burnt area traced during a field survey (b). Aerial view of the scene immediately after the

6 fire (c). Betula ermanii forest stands near the plot immediately after the fire (d).

7 Figure 2. Betula ermanii stands in scarification sites after 6 months in Plot 1 (a-b) and Plot 2

8 (c-d). Each plot was set to the position indicated by black squares (a, c). Scorched tree (e);

9 burnt and damaged tree (f); litter layer and burnt litter (g; black layer); and understory

10 vegetation and recovered Sasa kurilensis (the most dominant species) (h).

11 Figure 3. Stand structure of Betula ermanii in Plots 1 and 2. Histograms were created from

12 individual trunk diameter at breast height $(\mathrm{DBH})$ for each plot.

13 Figure 4. Binary logistic regression analysis of Betula ermanii as a function of trunk

14 diameter at breast height (DBH). Black points around the ' 1 ' line on the y-axis indicate

15 surviving trees and black points around the ' 0 ' line indicate dead trees. The solid blue line

16 represents the probability function derived from the prediction equation and the grey area

17 shows the $90 \%$ confidence interval.

Figure 5. Map of Sasa kurilensis on the forest floor at 6 (2019) and 16 months (2020) after the fire in each plot. Mapping was manually interpreted from orthomosaic images captured with UAVs at each period.

Figure 6. Cover rate of Sasa kurilensis estimated using UAV orthomosaic images. 
bioRxiv preprint doi: https://doi.org/10.1101/2020.09.20.305557; this version posted November 25, 2020. The copyright holder for this preprint (which was not certified by peer review) is the author/funder, who has granted bioRxiv a license to display the preprint in perpetuity. It is made available under aCC-BY-NC-ND 4.0 International license.

\section{Figure 1}
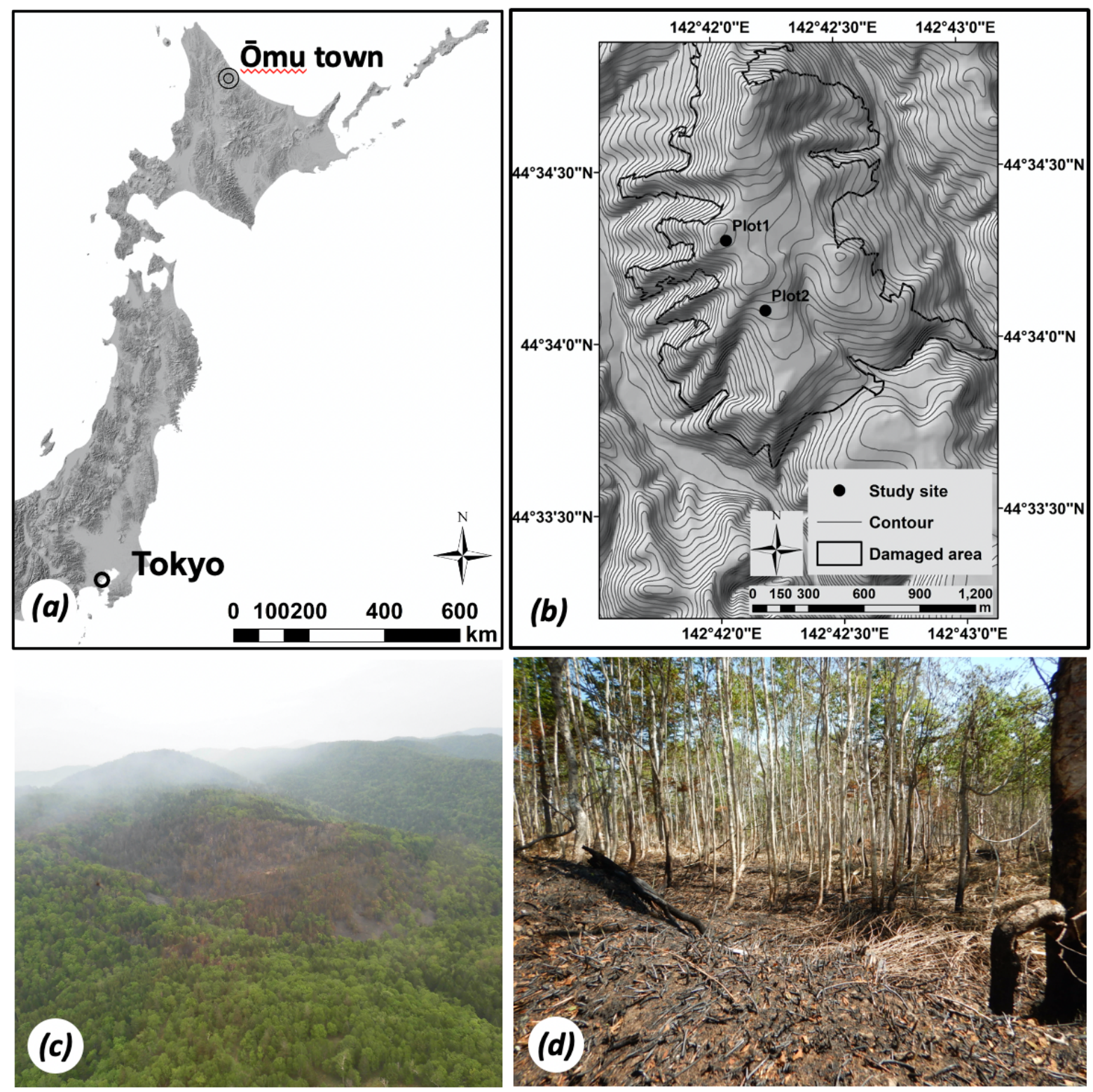
bioRxiv preprint doi: https://doi.org/10.1101/2020.09.20.305557; this version posted November 25, 2020. The copyright holder for this

preprint (which was not certified by peer review) is the author/funder, who has granted bioRxiv a license to display the preprint in perpetuity. It is made available under aCC-BY-NC-ND 4.0 International license.

Figure 2
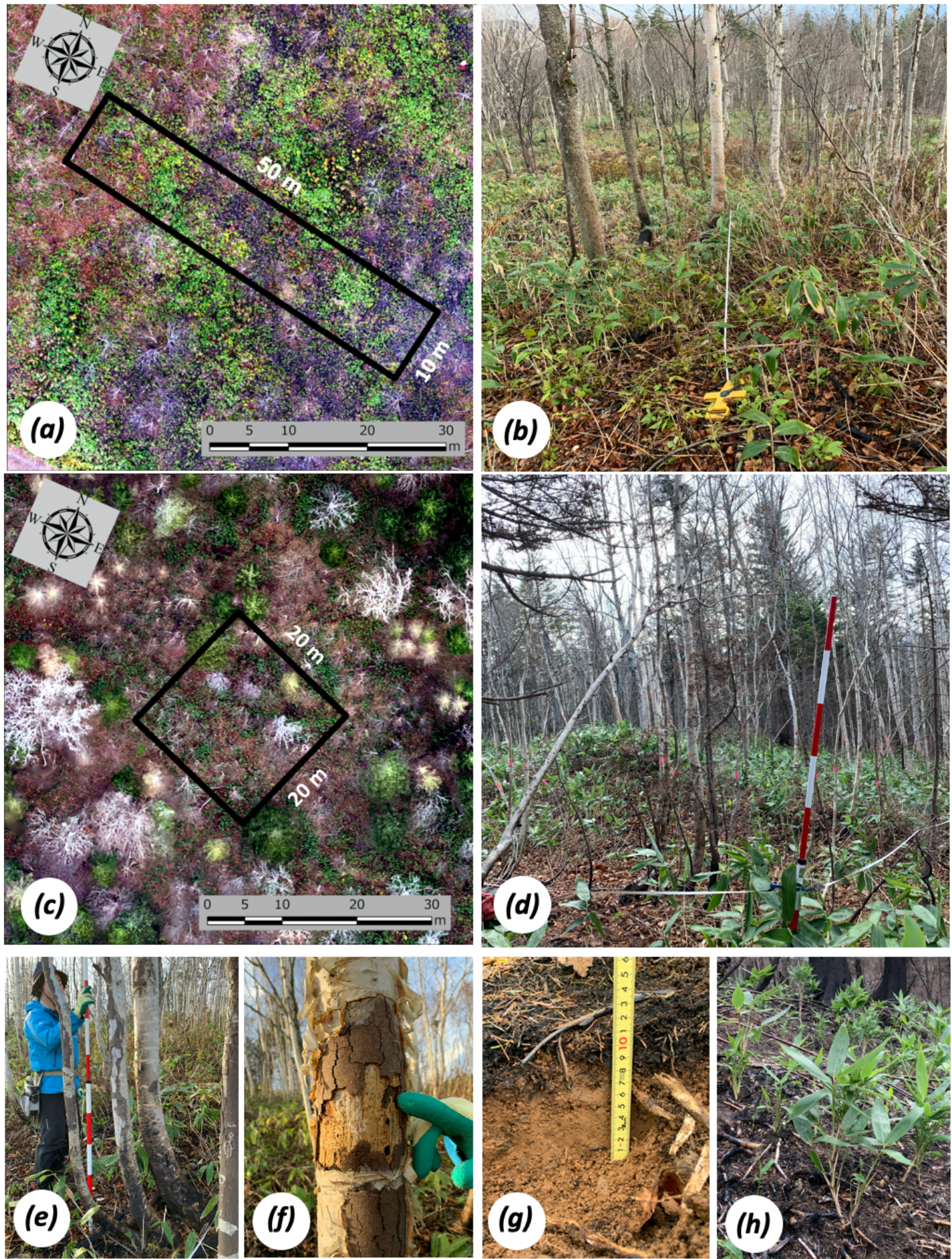

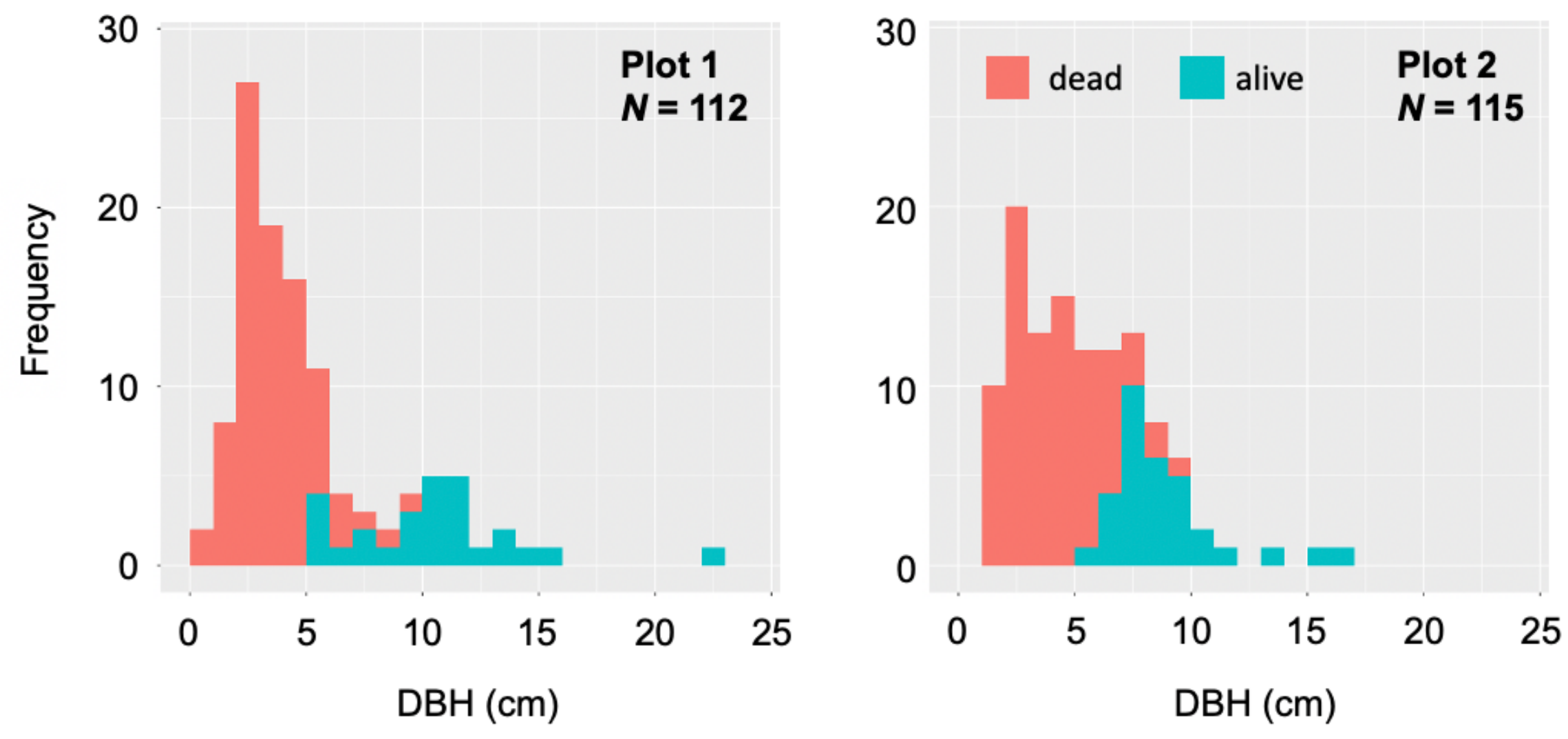

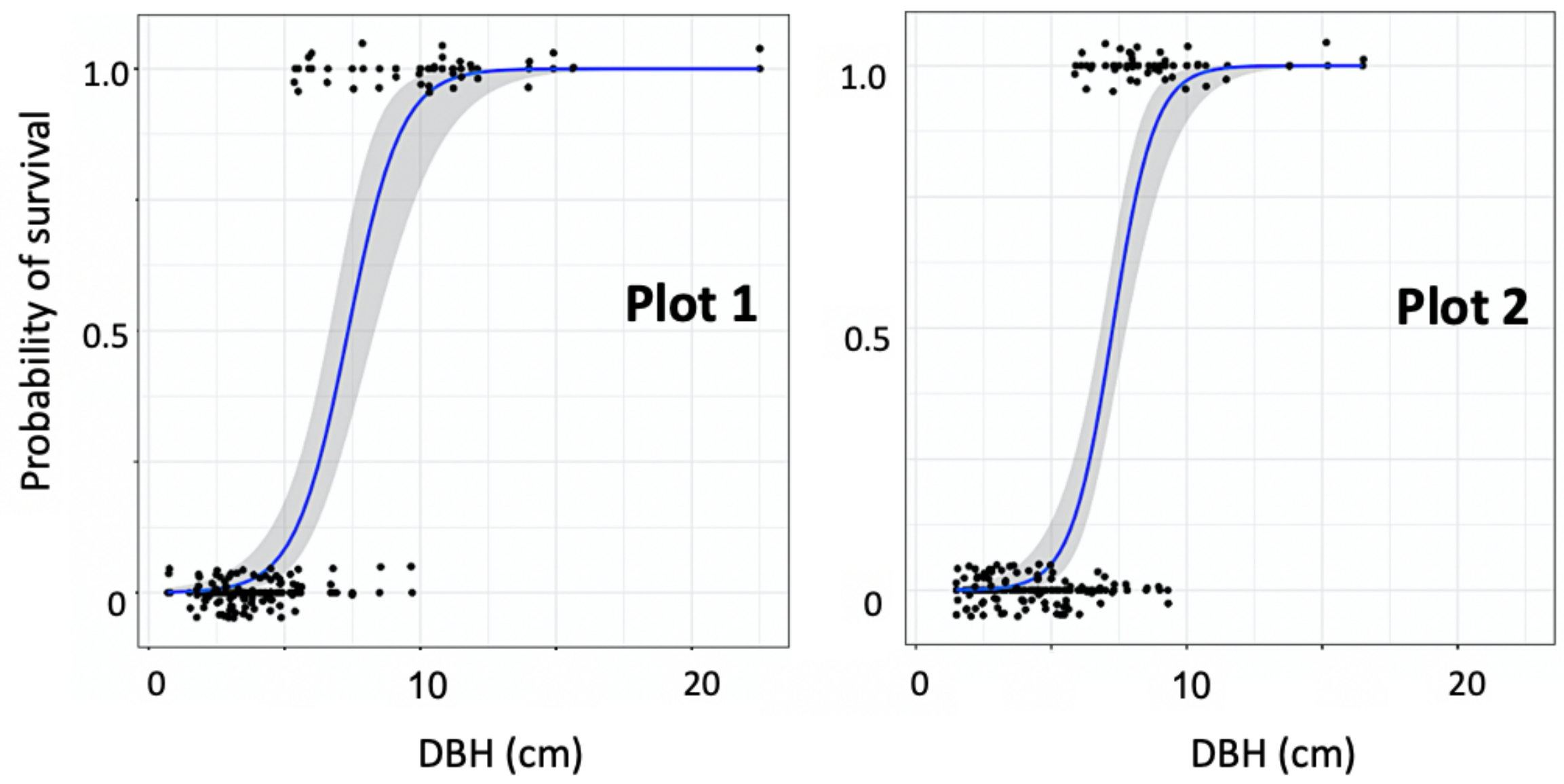


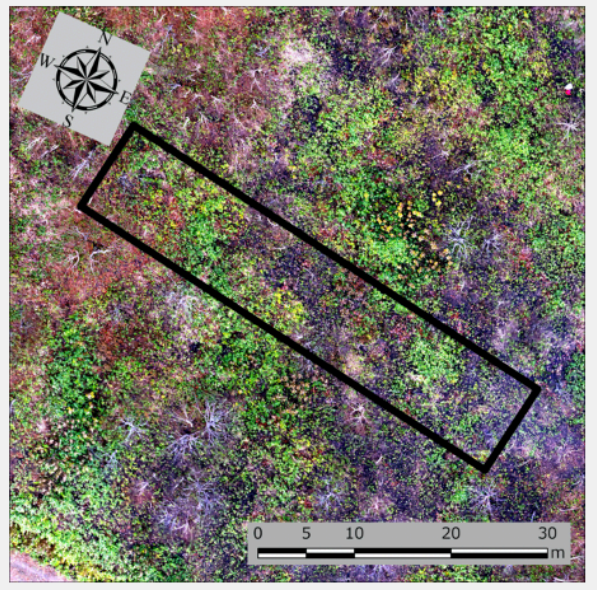

(a)

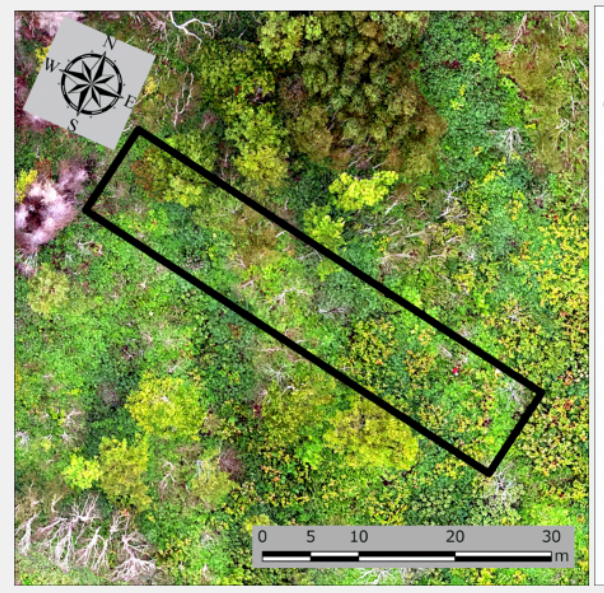

(c)
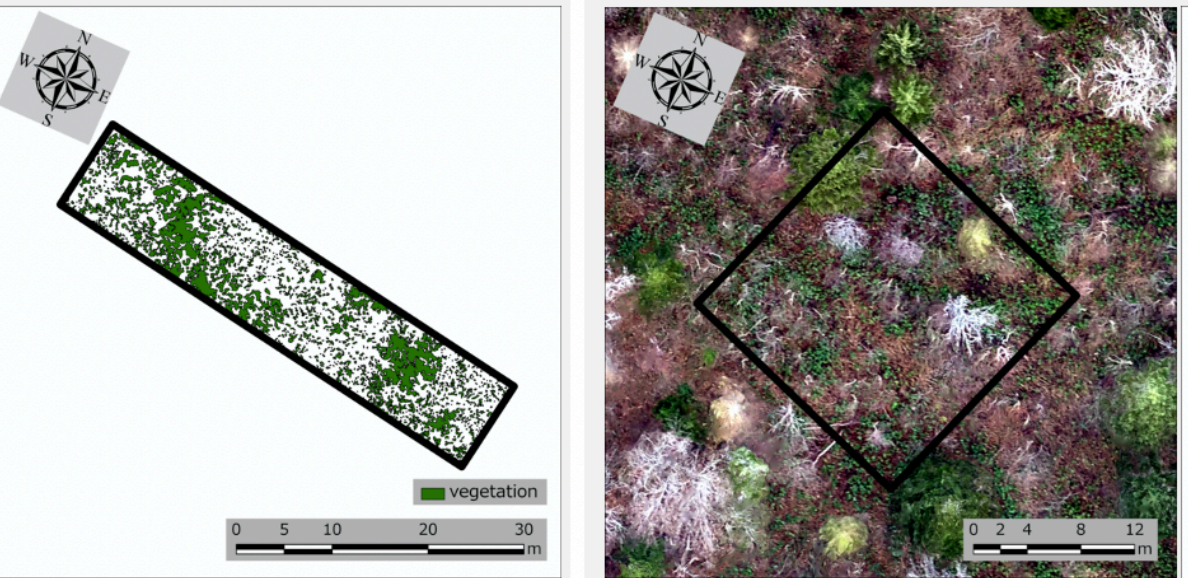

(b)
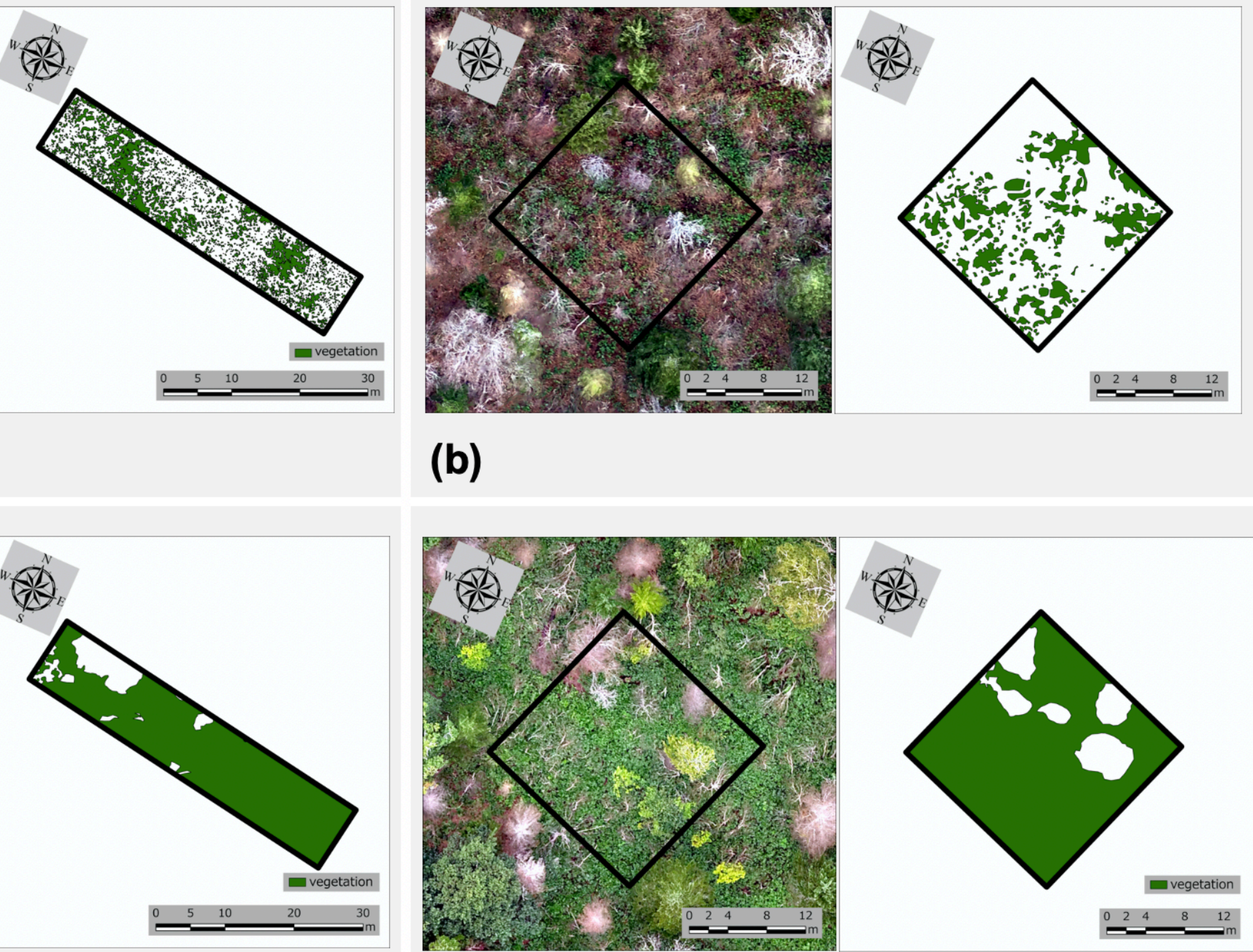

(c)

(d) 

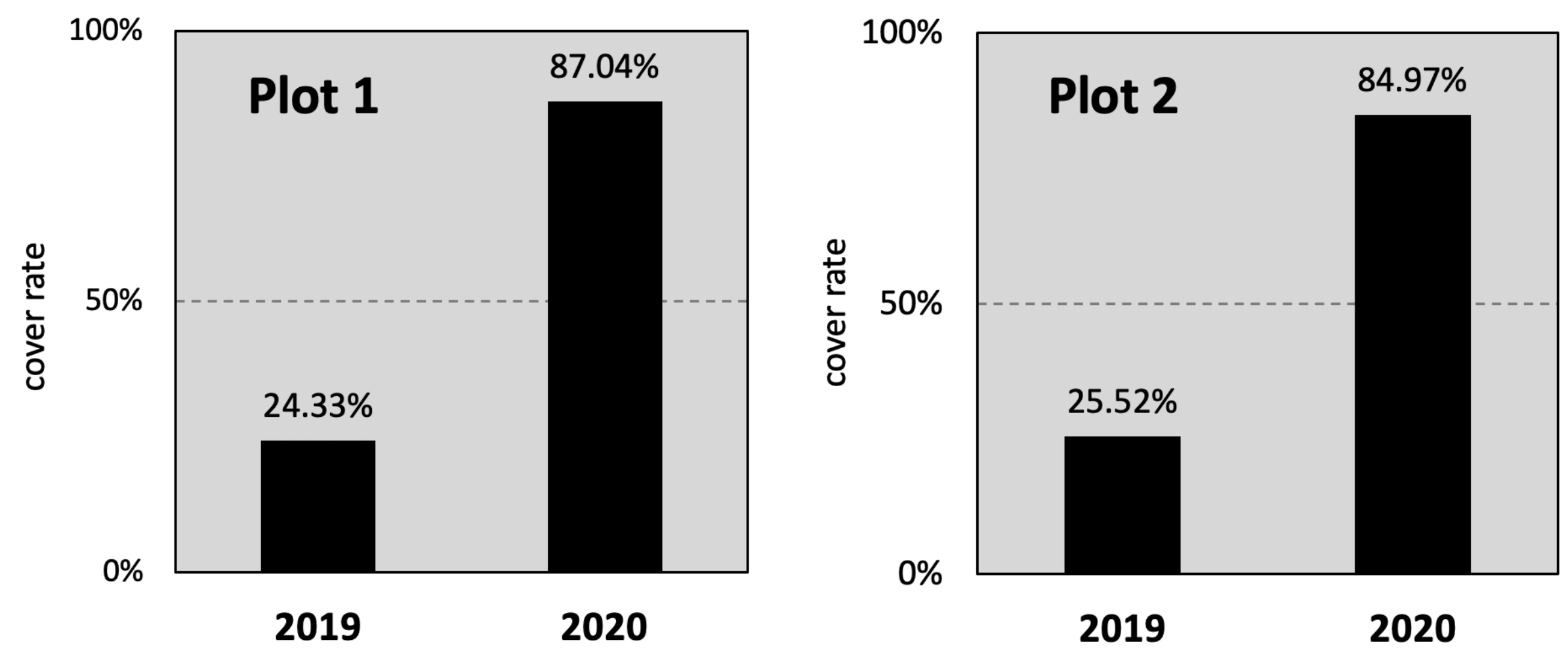


\section{Supplementary material}

2 1. Supplemental Table 1: Results of GLM analysis on the effects of DBH, Stem damage, and

3 Scorch height on probability of post fire survival of Betula ermanii. The terms with hyphen

4 indicate that they were not included in the models by model selection procedure.

5 2. Supplemental Figure 1: Orthomosaic images of Betula ermanii stands in scarification sites

6 in Plots 1 and 2 in 2020, 16 months post fire, using UAV (a). Betula ermanii stands covered

7 by dwarf bamboo in scarification sites after 6 months in Plot 1 (b) and Plot 2 (c). The

8 maximum culm height of dwarf bamboos were $94 \mathrm{~cm}$ in Plot 1 and $138 \mathrm{~cm}$ in Plot 2, as

$9 \quad$ indicated by the Level staff in the photo (b and $c)$. 
11 Supplement table 1 Results of GLM analysis on the effects of DBH, Stem damage, and Scorch height on probability of post fire survival of

12 Betula ermanii. The terms with hyphen indicate that they were not included in the models by model selection procedure.

\begin{tabular}{|c|c|c|c|c|c|}
\hline$d f$ & $\Delta \mathrm{AIC}$ & $\log L$ & $\mathrm{DBH}$ & Stem damage & Scorch height \\
\hline 2 & 0.000 & -44.984 & 1.148 & - & $\begin{array}{r}15 \\
-16\end{array}$ \\
\hline 3 & 1.600 & -44.784 & 1.152 & 0.008 & $\begin{array}{r}17 \\
-18\end{array}$ \\
\hline 3 & 1.960 & -44.965 & 1.151 & - & $0.001_{20}^{19}$ \\
\hline
\end{tabular}


bioRxiv preprint doi: https://doi.org/10.1101/2020.09.20.305557; this version posted November 25, 2020. The copyright holder for this

preprint (which was not certified by peer review) is the author/funder, who has granted bioRxiv a license to display the preprint in perpetuity. It is made available under aCC-BY-NC-ND 4.0 International license.

\section{Supplemental Figure 1}
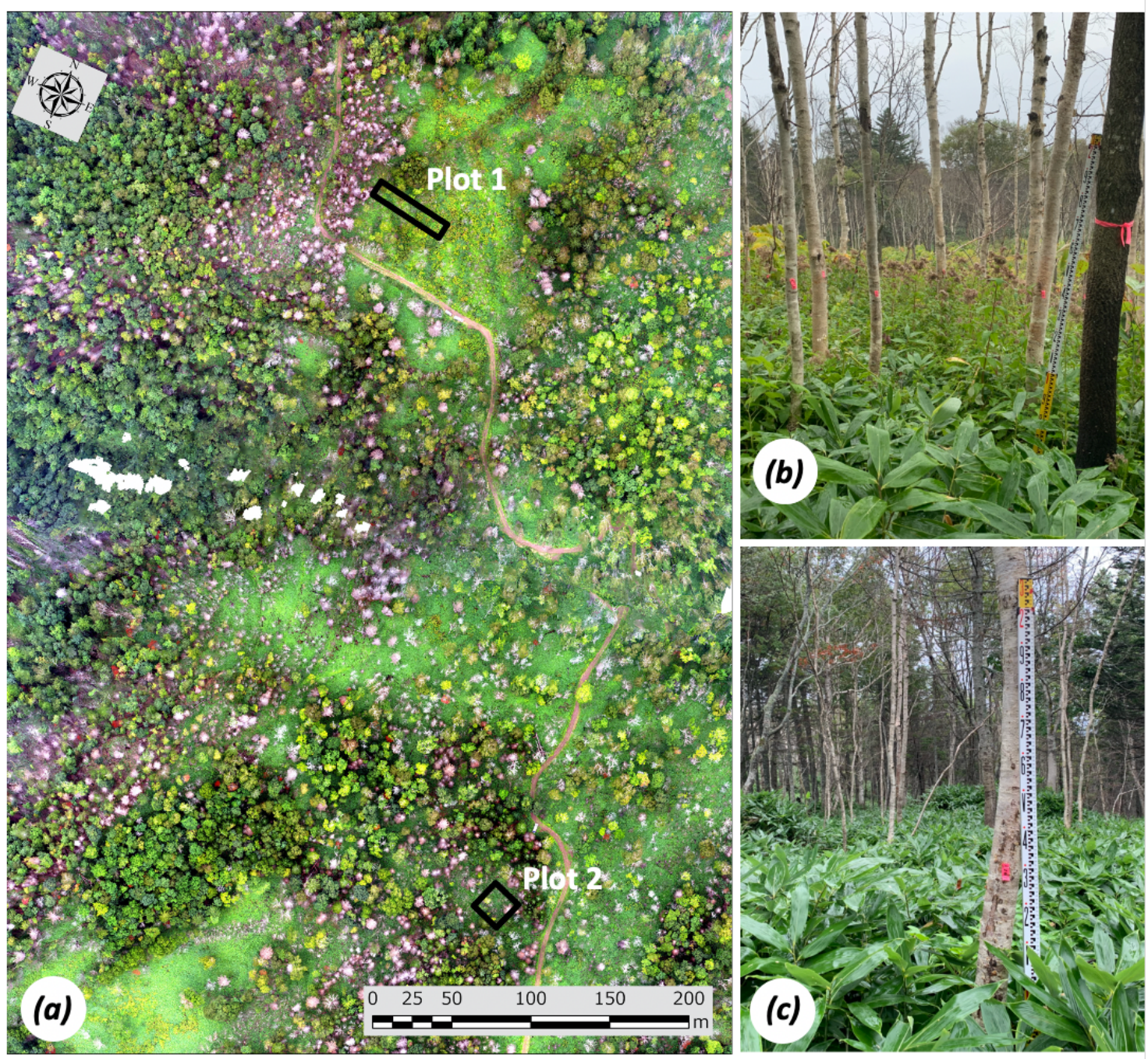